\section{1. 改良型小腸生検器について}

日本大 第 3 内科

○田川博之有賀久幸 杉村文昭 岩城勝英 五味清英 林 貴 雄 川島祐本田利男 有賀愧三

内視鏡検查器械の発達と診断技術の向上により, 食 道から十二指腸までの上部消化管についてはほとんど 盲点なくフアイバースコープによる直視下生検が行な われている.

最近は小腸フアイバースコープが開発され，さらに 深部一の内視鏡診断が可能になり鉗子，吸引生検も行 なわれるようになったが，標本の大きさ，挫滅の程度 にまだ解決すべき幾多の問題があるものと思われる. われわれは従来使われていた RUBIN 型小腸吸引生検 器に対しさらに使いやすく効率の上い日大型吸引生検 器を試作し臨床に用いているのでその特徴等について 報告する。

\section{2. 電動式内視鏡検查ベッドの使用経験}

日本大 第 3 内科

○桑 山肇服部俊男 鵜浦達也岩崎有良 岡田貞雄林貴雄 児泉肇高橋 淳 本田利男有賀愧三

消化管特に胃の内視鏡検查時にしばしば胃内に貯溜 した胃液等が多く観察困難であったり，ファイバース コープがミューカスレークに没してしまう場合があ る. また, 最近の診断技術の向上により微細病変の生 検やポリペクトミー, 緊急止血操作等の内視鏡施行時 に，至適な状態に患者の位置を動かす必要がある。

われわれは従来, 手動で患者の位置をトレンデレン ブルク体位に変えるのみであった内視鏡ベッドを，電 動により上下：左右：斜の各方向に変換できる内視鏡 検査台を考案したのでその臨床上のメリット等につき 報告する. 